\title{
The extent of differences between six British breeds of sheep in their metabolism, feed intake and utilization, and resistance to climatic stress
}

\author{
By K. L. BLAXTER, J. L. CLAPPERTON AND F. W. WAINMAN \\ Hannah Dairy Research Institute, Ayr
}

(Received 23 August 1965-Accepted I7 December I965)

\begin{abstract}
I. Thirty wether sheep comprising five of each of the following breeds, Scottish Blackface, Welsh Mountain, Cheviot, Suffolk Down, Kent and Hampshire Down, were subjected to a standard series of experiments in which energy metabolism was measured during fasting and at the maintenance level of nutrition, and in which maximal voluntary intake of food was measured and the metabolic responses to the stress of wind (10 miles/h) and rain $(1 \mathrm{~cm} / \mathrm{h})$ were determined. 2. The weight of an individual sheep at the maintenance level of feeding was $8.4 \%$ greater and when given feed ad lib. $22 \%$ greater than its weight when fasted. These increases largely reflected changes in the weight of gut contents. 3. When fasting metabolism was expressed per $\mathrm{kg}$ weight raised to the power o'73, the small Welsh Mountain sheep had the lowest metabolism of $54^{\cdot 1} \mathrm{kcal} / \mathrm{kg} W^{0 \cdot 73}$ and the Cheviot sheep the highest of $64^{\cdot 4} \mathrm{kcal} / \mathrm{kg}$ $W^{0.73}$. Overall breed differences were statistically significant $(0.05>P>0.01)$. Evidence collected in the experiments, however, suggests that fasting metabolism was more closely related to body-weight raised to the power 0.85 . When this basis for breed comparison was used, differences in fasting metabolism between breed groups disappeared. 4. No differences between breed groups in the proportion of the energy they ingested which was lost in faeces, in urine or as methane, were found when they were given food at a maintenance level. The Welsh Mountain sheep, however, had the smallest heat production at the maintenance level when expressed as $\mathrm{kcal} / \mathrm{kg} W^{0.73}$. 5. No differences between breed groups in the apparent digestibility of the energy of feed given ad lib. were found. The voluntary intake increased with weight of sheep. When the amount of feed energy consumed and the energy apparently digested were related to the determined maintenance requirement for apparently digested energy of each sheep, no differences between breed groups were found. The efficiency of feed utilization by these breed groups of sheep when given feed ad lib. was the same. 6 . It was found that the Hampshire sheep were the most resistant to the effect of wind on their heat production, and the Welsh Mountain sheep the least. The Scottish Blackface was most resistant to the effect of rain on heat production. 7. It is concluded that metabolic differences between different breeds of sheep differing widely in size are quite small, but that breeds differ markedly in their resistance to environmental stresses caused by wind and rain, and that these largely reflect the characteristic fleece types of the breeds concerned.
\end{abstract}

Britain is well endowed with breeds of sheep, many of which are recognized to be adapted to particular nutritional and climatic environments. Little, however, is known about the extent, if any, of metabolic differences between breeds. The studies described below were made primarily to find whether breeds differ with respect to the amount of feed they voluntarily consume relative to their maintenance requirements, that is the relative feeding level they attain, for earlier work had suggested that sheep with high maintenance requirements tended to eat more than those with low requirements (Blaxter, Wainman \& Davidson, I966). The opportunity was taken to measure fasting and maintenance energy needs, and voluntary intake, and also to estimate the effects of standard climates on the energy metabolism of sheep. 


\section{EXPERIMENTAL}

Sheep. Eight wether sheep of each of six breeds (Scottish Blackface, Welsh Mountain, Cheviot, Suffolk Down, Kent or Romney Marsh and Hampshire Down) were purchased. The Welsh Mountain sheep were known to have come from two separate flocks. The Hampshires, Suffolks, Scottish Blackface and Kents were from single flocks. The source of the Cheviots could not be traced but was probably a single flock. The animals were kept together for 4 months before the experiment began when five individuals of each breed were selected. The animals were then more than 9 months of age, uncertainty about their age arising from the wide dispersion of lambing dates in these breeds.

Experimental design. Each of the thirty sheep was subject to the same sequence of experimental treatment for 3 months as follows:

14 days training to diet and to the metabolic cages. Feed was given ad lib.

2I days in which feed was given ad lib., intake of feed and apparent digestibility of feed being measured during the final 8 days.

2I days in which feed was given at a rate of $32 \mathrm{~g} / \mathrm{kg}$ body-weight raised to the power 0.73 . This amount was estimated from preliminary measurements of the apparent digestibility of the diet to approximate maintenance needs. Metabolism was measured during the last 5 days of this period.

4 days of fasting in which metabolism was measured.

II days of recovery from fasting in which the maintenance intake of feed was re-established.

I4 days in which the animal was trained to wear a mask to permit measurements of the respiratory exchange.

7 days in which the respiratory exchange was measured in four different climatic environments.

The thirty animals were divided into five groups or replicates each containing one representative of each breed. Within each of these groups, the animals were divided into three pairs and the two animals of each pair underwent experiment simultaneously. The pairings were so arranged that one member of each breed was paired with a member of every other breed.

Feed. The same sample of dried grass containing $16 \cdot 4 \%$ crude protein on a dry basis was used throughout.

Measurements. Maximal intake was measured using the technique of Blaxter, Wainman \& Wilson (196r). The metabolic measurements were made in respiration chambers (Wainman \& Blaxter, 1958) and included determinations of energy loss in the excreta, oxygen consumption and carbon dioxide and methane production. The mask technique for measuring the respiratory exchange was that of Joyce (1964) and the environments were those in a room cooled to less than $5^{\circ}$ by refrigeration. A wind of Io miles/h was produced when required with fans, and rain at the rate of $1.0 \mathrm{~cm} / \mathrm{h}$ was simulated with a water spray. The animals were exposed to four environments, cold alone, cold with wind at ro miles/h, cold with continuous rain, cold with wind and continuous rain. Exposure was for $\mathrm{I} h$ without measurement followed by three measurements of the respiratory exchange, each of 20 min duration. 


\section{RESULTS}

\section{Body-weight}

The maintenance period of feeding followed immediately after one in which food was offered ad lib. A change in weight over the maintenance period is unlikely to include any appreciable change in the fat, protein and water content of the body tissues and must largely reflect a change in gut contents. The same argument applies to the change in body-weight over the 4 days of fasting.

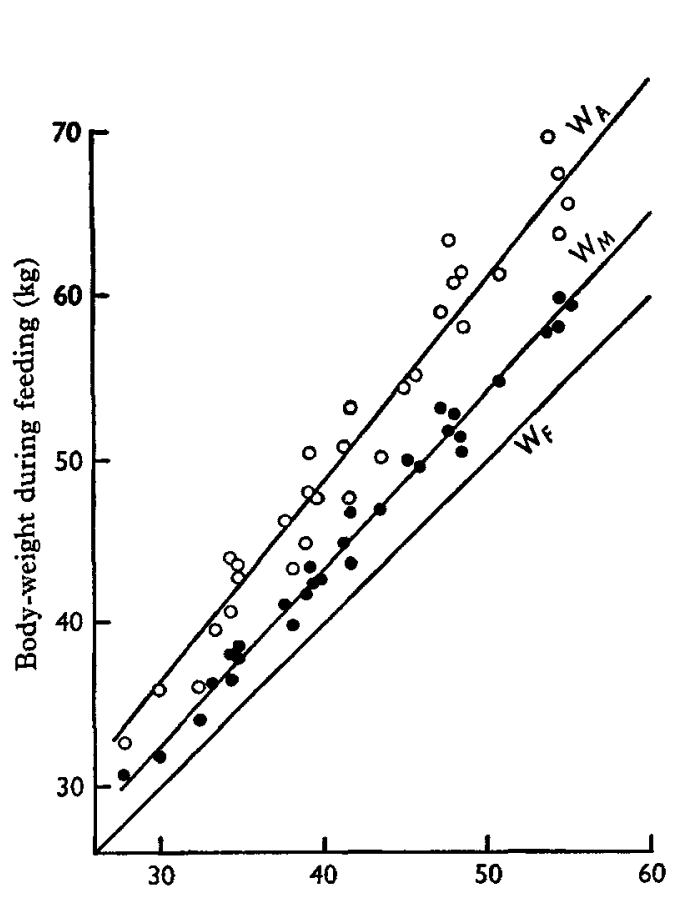

Body-weight during fasting $W_{F}(\mathrm{~kg})$

Fig. I

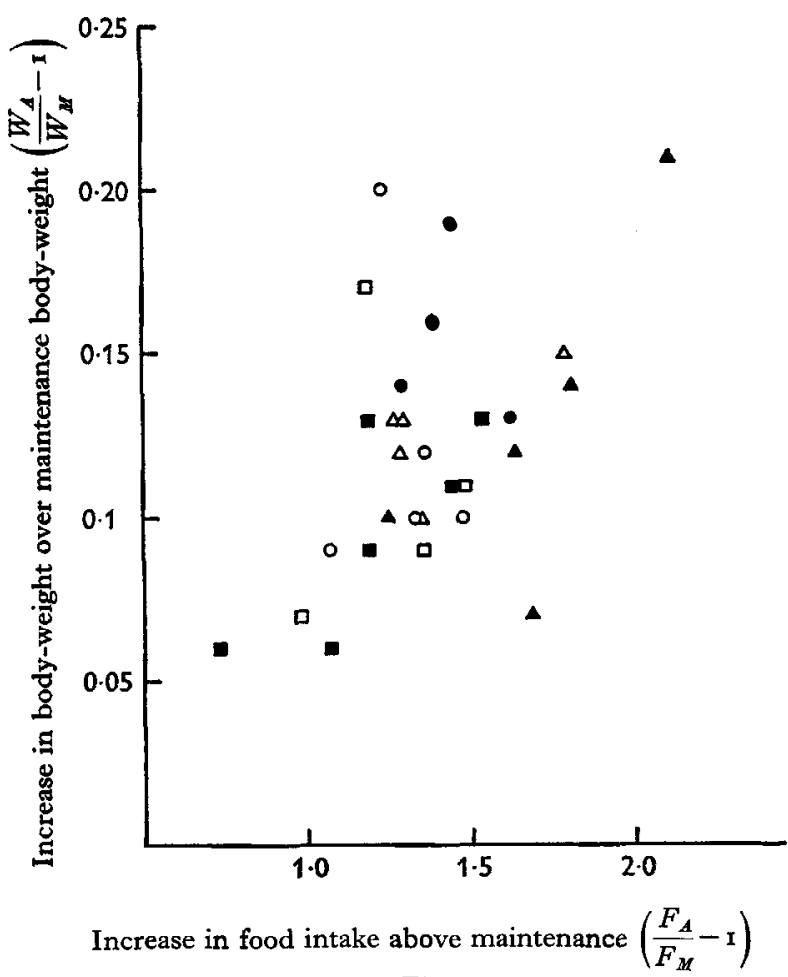

Fig. 2

Fig. I. Body-weight of thirty sheep at the maintenance level of feeding $\left(W_{M}\right)$, $\bullet$, and when fed $a d$ lib. $\left(W_{A}\right), 0$, plotted against body-weight during fasting $\left(W_{F}\right)$. The lines have the slopes $\mathrm{I} \cdot 000$ for fasting weight, $\mathrm{I} \cdot 084$ for maintenance weight and $\mathrm{I} \cdot 220$ for weight when fed $a d$ lib.

Fig. 2. Proportional increase in the body-weight of thirty sheep from maintenance $\left(W_{M}\right)$ to ad lib. feeding $\left(W_{A}\right)$ plotted against the proportional increases in food consumption. Values are given for the breeds: $\bullet$, Scottish Blackface;, , Welsh Mountain; $\bullet$, Cheviot; $\odot$, Suffolk Down; $\square$, Kent; and $\Delta$, Hampshire Down.

Fig. I shows the body-weights of the sheep at the maintenance level and when offered food ad lib. plotted against body-weight after a few days without food. Linear regression analysis showed that the intercept terms of regressions of maintenance weight $\left(W_{M}\right)$ and weight when feed was offered $a d l i b .\left(W_{A}\right)$ on fasting weight $\left(W_{F}\right)$ were not significantly different from zero. The weights were thus directly proportional to fasting weight, $W_{M}=\mathrm{I} \cdot 084 W_{F}$ and $W_{A}=\mathrm{I} \cdot 220 W_{F}$. These results suggest that with this diet the increase in the weight of digestive tract contents when feed intake 
was increased from fasting to maintenance was $8.4 \%$ of fasted weight, and at full feed it was 22.0\% of fasting weight. Much of the variation of $W_{A}$ about the line in Fig. $\mathbf{r}$, which is $W_{A}=\mathbf{1} \cdot 22 W_{F}$, is accounted for by variation in the increase in food intake from the maintenance level to the ad lib. level. In Fig. 2 the relation between $W_{A} / W_{M}-\mathrm{I}$ and $F_{A} / F_{M}-\mathrm{I}$ where $F$ is the dry food intake has been plotted. From the relationship given above the change in body-weight from maintenance to ad lib. feeding would be $W_{A}=\mathrm{I} \cdot 22\left(W_{M} / 1 \cdot 08\right)=I_{1} \cdot W_{M}$, that is an average increase of I3\%. Fig. 2 shows that those sheep which consumed most food relative to their maintenance food intake also showed the greatest percentage change in body-weight. One sheep which ate $3 \cdot 1$ times as much food as the maintenance allowance increased its body-weight by $21 \%$ and another which ate only $70 \%$ more food than it did at maintenance increased in weight by only $6 \%$. The regression of the proportional change in weight from maintenance to $a d l i b$. feeding on the proportional change in food intake was highly significant $(P<0.01)$.

These results suggest that considerable care must be used in the choice of a bodyweight to which to refer intakes of food and from which to calculate the maintenance needs required to compute relative feeding levels. For this reason, when possible results have been expressed without direct reference to body-weight, and when weight comparisons have been used, it has been made clear which weight is meant.

\section{Fasting metabolism}

Fig. 3 shows fasting heat production plotted against body-weight during fasting, with the results for the six breeds indicated by separate symbols. For each of the breeds both linear and log-log regressions were calculated of fasting metabolism on body-weight during fasting. There were no differences between these regressions based as they were on relatively few values, nor were there significant deviations between breed means from a pooled within-breed regression. The pooled regressions in which breed differences were ignored were

$$
\begin{gathered}
Q_{F}=\mathrm{I} 59+\mathrm{I} 7 \cdot 3 W_{F}, \text { residual standard deviation } \pm 86 \mathrm{kcal} / \mathrm{day}, \\
Q_{F}=37 \cdot 3 W_{F}{ }^{0.85}, \text { residual standard deviation approximately } \pm \mathrm{I} \mathrm{I} 7 \mathrm{kcal} / \mathrm{day},
\end{gathered}
$$

where $Q_{F}$ is fasting heat production in $\mathrm{kcal} / \mathrm{day}$ and $W_{F}$ is fasting body-weight in $\mathrm{kg}$.

Table I gives the mean body-weights during fasting and fasting heat productions of the breeds together with the fasting heat productions per $\mathrm{kg} W_{F}{ }^{0.73}$. Though during fasting there were large and highly significant differences between the weights and metabolisms of the breed groups, the differences between the metabolisms expressed per $\mathrm{kg} W_{F^{0}}^{0.73}$ were significant only when $P=0.05$. This difference was largely accounted for by the difference in the metabolism of the small Welsh and large Cheviot sheep. If, as the complete analysis suggests, the metabolism of these six breeds of sheep was closer to weight raised to the power 0.85 than to weight raised to the power 0.73 , these differences disappear. 


\section{Metabolism at the maintenance level}

Table 2 summarizes the actual measurements made at the maintenance level of feeding, and Figs. 4, 5 and 6 show heat production, $\mathrm{CH}_{4}$ production and urine energy of individual sheep plotted against their body-weight when fed for maintenance. From values given in Table 2 together with those in Table $I$, the values given in Table 3 were calculated.

As shown in Table 3, there were no differences between breeds in their ability to ferment and digest the diet, or in the metabolizable energy they obtained from unit weight of it. Breeds differed in the amount of apparently digested energy required

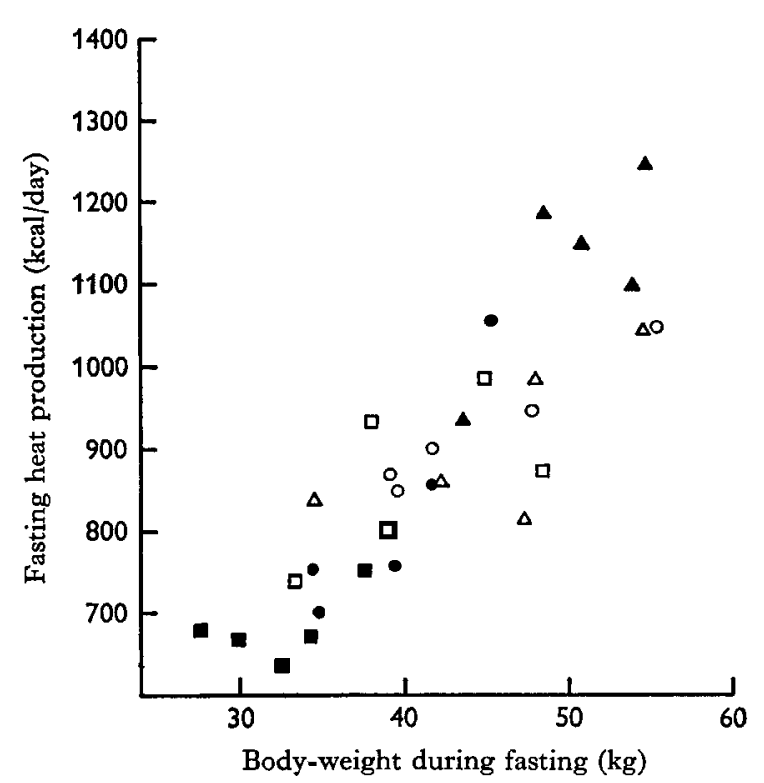

Fig. 3. Relation during fasting between heat production and body-weight in thirty sheep of six breeds. The symbols used for the six breeds are listed in the legend to Fig. 2.

Table I. Mean body-weight during fasting, fasting heat production and heat production/

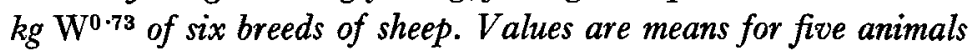

\begin{tabular}{|c|c|c|c|c|}
\hline Breed & $\begin{array}{l}\text { Fasted } \\
\text { weight } \\
W_{F}(\mathrm{~kg})\end{array}$ & $\begin{array}{c}\text { Fasting } \\
\text { heat } \\
\text { production } \\
Q_{F}(\text { kcal/ } \\
24 \mathrm{~h})\end{array}$ & $\begin{array}{c}\text { Fasting } \\
\text { urine } \\
\text { energy } \\
(\mathrm{kcal} / 24 \mathrm{~h})\end{array}$ & $\begin{array}{c}\text { Fasting } \\
\text { heat } \\
\text { production } \\
Q_{F}(\mathrm{kcal} / \mathrm{kg} \\
\left.W_{F^{\mathbf{0} 73}}\right)\end{array}$ \\
\hline $\begin{array}{l}\text { Scottish Blackface } \\
\text { Welsh Mountain } \\
\text { Cheviot } \\
\text { Suffolk Down } \\
\text { Kent } \\
\text { Hampshire Down }\end{array}$ & $\begin{array}{l}39 \cdot 1 \\
32 \cdot 3 \\
50 \cdot 3 \\
44 \cdot 7 \\
40 \cdot 9 \\
45 \cdot 3\end{array}$ & $\begin{array}{r}828 \\
682 \\
\text { I } 124 \\
922 \\
866 \\
908\end{array}$ & $\begin{array}{l}64 \cdot 9 \\
35 \cdot 2 \\
79 \cdot 6 \\
53 \cdot 5 \\
48 \cdot 1 \\
55 \cdot 9\end{array}$ & $\begin{array}{l}56 \cdot 6 \\
54 \cdot 1 \\
64 \cdot 4 \\
57 \cdot 8 \\
58 \cdot 0 \\
56 \cdot 5\end{array}$ \\
\hline $\begin{array}{l}\text { Standard error of means } \\
\text { Significance of differences } \\
\text { between breeds }\end{array}$ & $\begin{array}{l} \pm 4.1 \\
P<0.001\end{array}$ & $P<0.001$ & $P<0.001$ & $\begin{array}{l}0.05> \\
P>0.01\end{array}$ \\
\hline
\end{tabular}


Table 2. Energy balance in five sheep of each of six breeds given an amount of feed estimated to be sufficient to maintain weight, and resultant energy retentions

Breed

Scottish Blackface Welsh Mountain

Cheviot

Suffolk Down

Kent

Hampshire Down

\begin{tabular}{rrrrrr}
$\begin{array}{c}\text { Energy } \\
\text { intake }\end{array}$ & $\begin{array}{c}\text { Faeces } \\
\text { energy }\end{array}$ & $\begin{array}{c}\text { Urine } \\
\text { energy }\end{array}$ & $\begin{array}{c}\mathbf{C H}_{\mathbf{4}} \\
\text { energy }\end{array}$ & $\begin{array}{c}\text { Heat } \\
\text { produced }\end{array}$ & $\begin{array}{c}\text { Energy } \\
\text { retained }\end{array}$ \\
\multicolumn{7}{c}{ (kcal/24 h) } \\
2200 & 656 & 139 & 171 & 1424 & -190 \\
1839 & 563 & 94 & 128 & 1078 & -24 \\
2552 & 727 & 159 & 188 & 1672 & -194 \\
2330 & 688 & 131 & 172 & 1534 & -195 \\
2143 & 680 & 123 & 150 & 1393 & -203 \\
2366 & 770 & 138 & 171 & 1522 & -235
\end{tabular}

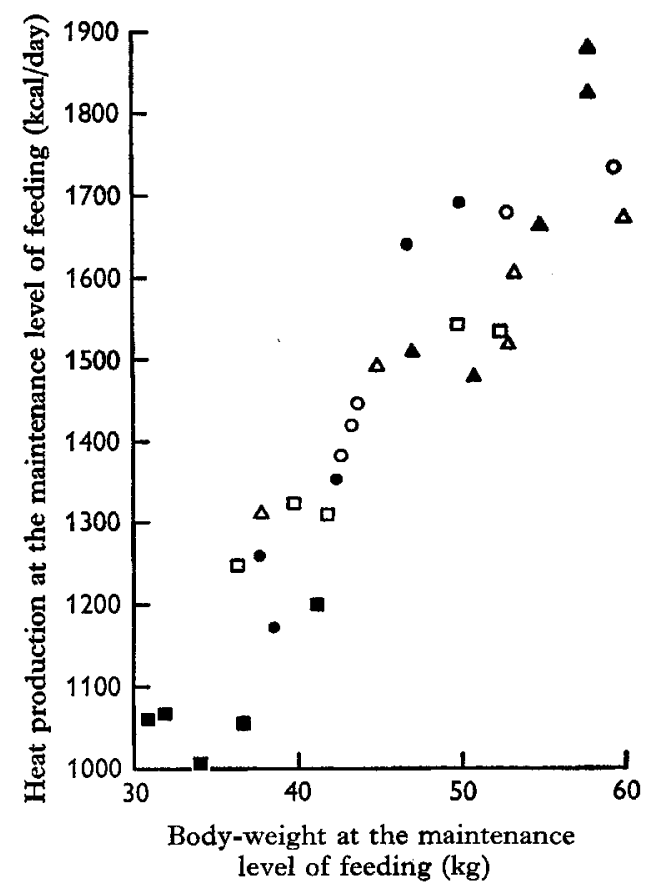

Fig. 4

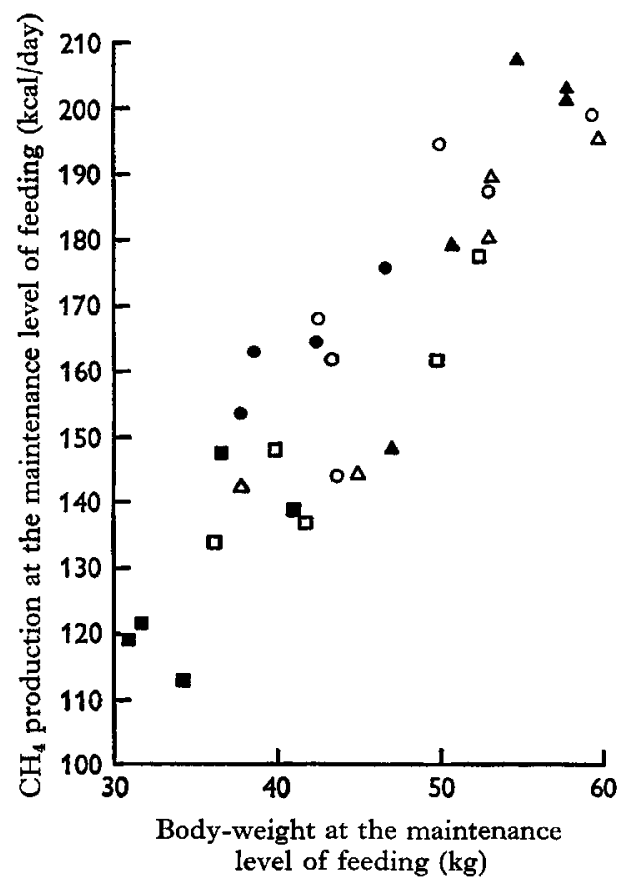

Fig. 5

Fig. 4. Relation at the maintenance level of feeding between heat production and body-weight in thirty sheep of six breeds. The symbols used for the six breeds are listed in the legend to Fig. 2.

Fig. 5. Relation at the maintenance level of feeding between $\mathrm{CH}_{4}$ production and body-weight in thirty sheep of six breeds. The symbols used for the six breeds are listed in the legend to Fig, 2.

to maintain a zero energy retention, but this was largely due to body size, for differences tended to disappear when maintenance needs were expressed per $\mathrm{kg}$ fasting weight raised to the power 0.73 . In agreement with the observations on fasting heat production, however, the Welsh Mountain sheep had a significantly lower heat production than the other breeds at the maintenance level of feeding. 


\section{Maximal voluntary intakes of food}

Mean values for the dry-matter intake of and the apparent digestibility of energy by the sheep when offered food ad lib. are summarized in Table 4 and in Fig. 7, where the amount of energy taken in and apparently digested has been plotted against body-weight determined when the sheep were offered food ad lib. The range of intake was considerable. One Cheviot weighing at maintenance $55 \mathrm{~kg}$ consumed $1962 \mathrm{~g}$ dry matter/day and one Welsh Mountain sheep weighing at maintenance $34 \mathrm{~kg}$ consumed only $732 \mathrm{~g}$ dry matter/day.

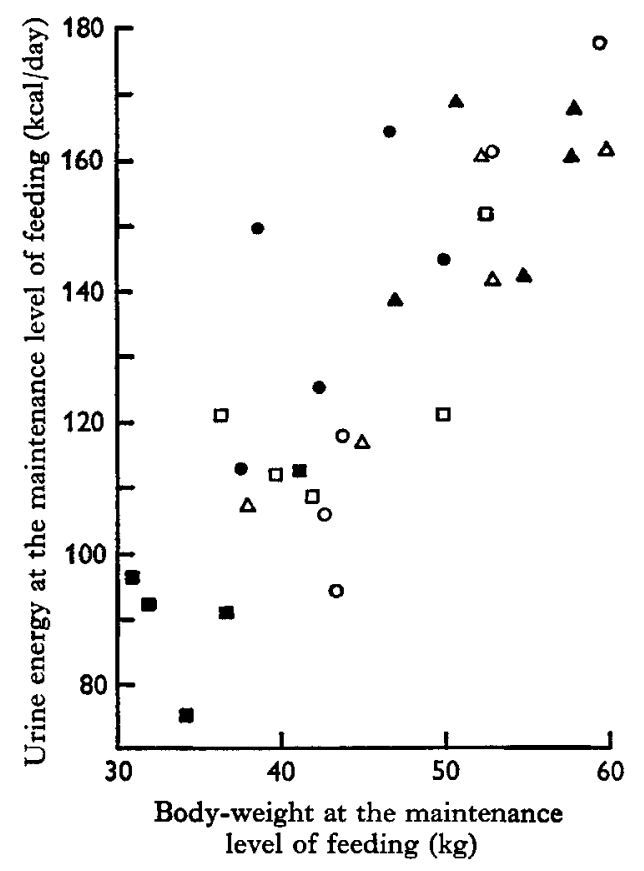

Fig. 6. Relation at the maintenance level of feeding between the heat of combustion of the urine and body-weight in thirty sheep of six breeds. The symbols used for the six breeds are listed in the legend to Fig. 2.

The apparent digestibility of the energy of the food fell significantly from a mean of $71 \cdot 6 \pm 0.52 \%$ to $68 \cdot 1 \pm 0.45 \%$ when intake increased from the maintenance level to the maximum amount the sheep would eat. The absolute amounts of dry matter and of apparently digested energy consumed varied considerably and significantly from breed group to breed group. Much of this was clearly due to body size, and the statistical significance of differences fell when dry-matter intakes were expressed per $\mathrm{kg} W^{0 \cdot 73}$.

To compare the groups in terms of their intakes of feed energy relative to their maintenance needs, the actual intake of energy when feed was given ad lib. has been divided by the determined maintenance requirements of energy as summarized in Table 3. This comparison avoids using a reference weight. When this is done, the results given in the last column of Table 4 are obtained. Analysis of variance of these 
results showed that there were no significant differences between the individual breeds (value of $F=2.25$ for 5 and 20 degrees of freedom, when $P=0.05, F=2.71$ ). When from the 5 degrees of freedom for breed group comparisons a single

Table 3. Apparent digestibility of dietary energy and energy of urine and $\mathrm{CH}_{4}$ as a percentage of dietary energy, as determined at the maintenance level, and the calculated requirement of digested energy to maintain weight in sheep. Values are means for five sheep of each breed

\begin{tabular}{|c|c|c|c|c|c|c|}
\hline & & & & & $\begin{array}{r}\text { Apparently } \\
\text { ener }\end{array}$ & $\begin{array}{l}\text { ly digested } \\
\text { ergy }\end{array}$ \\
\hline Breed & $\begin{array}{c}\text { Apparent } \\
\text { digesti- } \\
\text { bility } \\
\text { of energy } \\
(\%)\end{array}$ & $\begin{array}{l}\text { Urine } \\
\text { energy } \\
\text { (\% of } \\
\text { intake) }\end{array}$ & $\begin{array}{c}\mathrm{CH}_{4} \\
\text { energy } \\
\text { (\% of } \\
\text { intake) }\end{array}$ & $\begin{array}{c}\text { Meta- } \\
\text { bolizable } \\
\text { energy } \\
\text { (\% of } \\
\text { intake) }\end{array}$ & $\begin{array}{c}\text { Required } \\
\text { for } \\
\text { maintenance* } \\
(\mathrm{kcal} / 24 \mathrm{~h})\end{array}$ & $\begin{array}{c}\text { Required } \\
\text { for } \\
\text { maintenance } \\
\text { relative to } \\
\text { body size } \\
\text { during } \\
\text { fasting } \\
\text { (kcal/kg } \\
\left.W^{0.73} 24 \mathrm{~h}\right)\end{array}$ \\
\hline h Blackface & $72 \cdot 7$ & 6.4 & $7 \cdot 8$ & $5^{6 \cdot 2}$ & 1736 & I I 6.I \\
\hline h Mountain & $71 \cdot 3$ & $5 \cdot 1$ & $8 \cdot 0$ & $57 \cdot 3$ & 1297 & 103.4 \\
\hline & $73 \cdot 3$ & $6 \cdot 2$ & $7 \cdot 4$ & $5^{8 \cdot 2}$ & 2154 & $123 \cdot 2$ \\
\hline lk Down & $72 \cdot 5$ & $5 \cdot 6$ & $7 \cdot 4$ & $57 \cdot 7$ & 2014 & 126.0 \\
\hline & $70 \cdot 5$ & $5 \cdot 8$ & $7 \cdot 1$ & $55 \cdot 6$ & 1927 & 129.1 \\
\hline pshire Down & 69.5 & $5 \cdot 8$ & $7 \cdot 2$ & 54.4 & 2074 & 129.4 \\
\hline dard error of & $\pm I \cdot 62$ & \pm 0.35 & \pm 0.21 & $\pm I \cdot 50$ & \pm 93 & \pm 6.6 \\
\hline $\begin{array}{l}\text { ificance of } \\
\text { ferences between } \\
\text { eeds }\end{array}$ & NS & NS & NS & NS & $P<0.001$ & $\begin{array}{l}0.05> \\
P>0.01\end{array}$ \\
\hline
\end{tabular}

NS, not significant.

* Calculated from the fasting katabolism and the efficiency of utilization of digested energy in the maintenance trials.

Table 4. Dry matter intake, apparent digestibility of energy and feeding level attained in five sheep of each of six breeds given food ad lib.

Breed

Scottish Blackface

Welsh Mountain

Cheviot

Suffolk Down

Kent

Hampshire Down

Standard error of means

Significance of differ between breeds

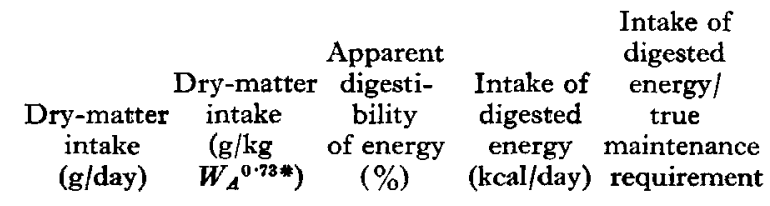

$\begin{array}{rrrrr}\text { II73 } & 68.6 & 70.3 & 3570 & 2.08 \\ 910 & 63.1 & 68.6 & 2736 & 2 \cdot 11 \\ 1535 & 76.6 & 67.3 & 4321 & 2.03 \\ 1201 & 69.4 & 67.7 & 3480 & 1.72 \\ 1078 & 63.1 & 67.1 & 3013 & 1.56 \\ 1278 & 67.5 & 67.5 & 3642 & 1.79 \\ \pm 71 & \pm 2.9 & \pm 1.15 & \pm 210 & \pm 0.15 \\ & & & & \text { NS } \\ P<0.001 & 0.05> & \text { NS } & P<0.001 & \text { NS } \\ & P>0.01 & & & \end{array}$

NS, not significant.

$* W_{A}=$ body-weight when food was given $a d l i b$. 
Vol. 20

degree of freedom was extracted representing the type of sheep (hill or lowland) a significant difference was found $(P<0.01)$, but the residual variance representing variation of breeds within types of sheep was less than the error variance. This throws

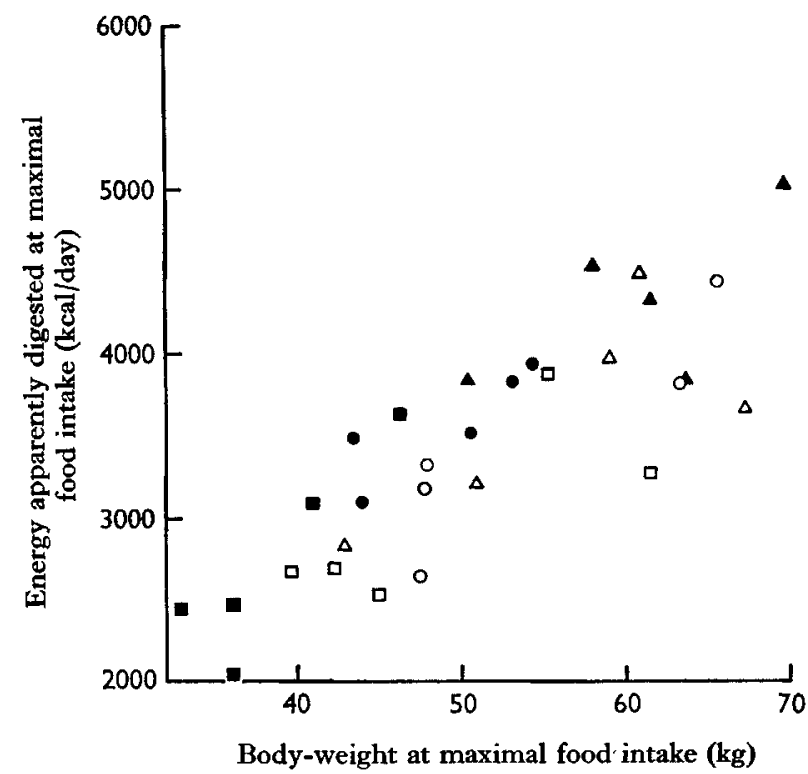

Fig. 7. Relation between the amount of food eaten and digested, expressed as apparently digested energy, and body-weight in thirty sheep of six breeds given the same food ad lib. The symbols used for the six breeds are listed in the legend to Fig. 2.

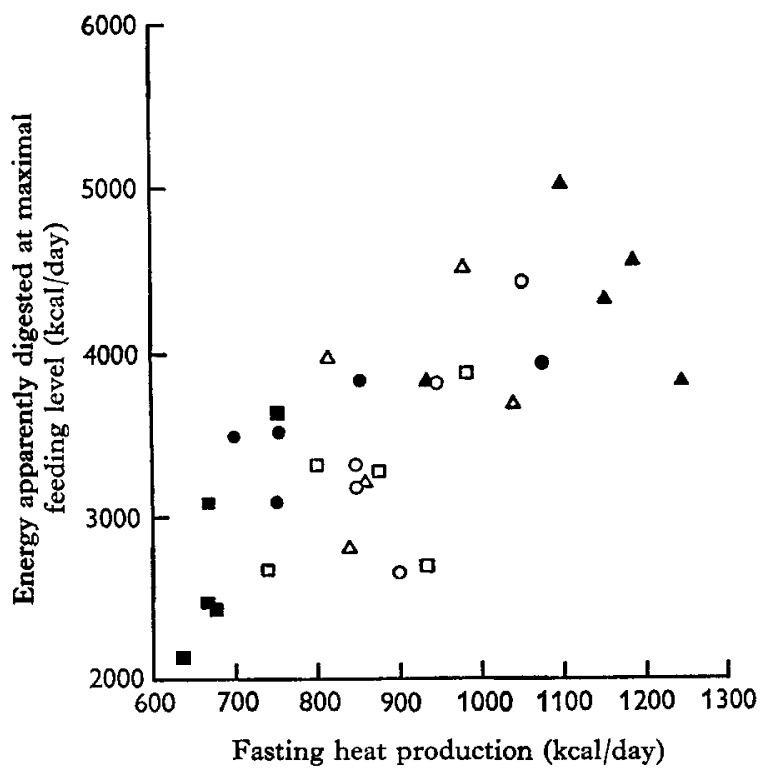

Fig. 8. Relation between the amount of food eaten and digested, expressed as apparently digested energy, and fasting metabolism in thirty sheep of six breeds given the same food $a d l i b$. The symbols used for the six breeds are listed in the legend to Fig. 2. 
doubt on the validity of a conclusion that the hill breeds were more efficient than the lowland breeds. From Fig. 8 which shows individual values for both digested energy intake and fasting heat production, the latter being a directly measured quantity, there is no clear-cut separation of lowland from hill sheep. This supports the conclusion that the hill breeds are not superior in efficiency of food utilization.

\section{Resistance to climatic stress}

Owing to a rise in air temperature during part of the year and to difficulties in training some of the animals to wear a mask, only three complete replicates of the trial were made, and with the Welsh Mountain breed one set of observations was missed. The mean results expressed in terms of the $24 \mathrm{~h}$ heat production are given in Table 5. It was not expected that the environment in the cold room when no wind or rain was produced would increase metabolism because the temperature was $3-5^{\circ}$, which

Table 5. Changes in the metabolism of six breeds of sheep on exposure to low air temperature, wind and rain

\begin{tabular}{|c|c|c|c|c|c|c|}
\hline & $\begin{array}{l}\text { No. of } \\
\text { sheep }\end{array}$ & $\begin{array}{l}\text { Metabolism } \\
\text { in cold } \\
\text { room }\end{array}$ & $\begin{array}{l}\text { Increase } \\
\text { due to } \\
\text { wind of } \\
\text { ro miles } / \mathrm{h}\end{array}$ & $\begin{array}{l}\text { Increase } \\
\text { due to rain }\end{array}$ & $\begin{array}{c}\text { Increase due } \\
\text { to rain and } \\
\text { wind } \\
\text { together }\end{array}$ & $\begin{array}{l}\text { Metabol- } \\
\text { ism in warm } \\
\text { respiration } \\
\text { chamber* }\end{array}$ \\
\hline Breed & \multicolumn{6}{|c|}{$(\mathrm{kcal} / 24 \mathrm{~h})$} \\
\hline Scottish Blackface & 3 & IOI 4 & +332 & +849 & +1211 & 1216 \\
\hline Welsh Mountain & 2 & 984 & +341 & +928 & +1000 & $103 I$ \\
\hline Cheviot & 3 & I 549 & +325 & +1534 & +2109 & 1624 \\
\hline Suffolk Down & 4 & 1268 & +212 & +789 & +1358 & I 497 \\
\hline Kent & 4 & 1067 & +246 & +782 & +1032 & 1297 \\
\hline Hampshire Down & 4 & 1196 & +58 & +721 & $+86_{3}$ & 1443 \\
\hline
\end{tabular}

Table 6. Mean conductance of heat from deep in the body of the sheep to the air on exposure of six breeds of sheep to low air temperature, wind and rain $\left(k c a l / m^{2} 24 h^{\circ} \mathrm{C}\right)$

\begin{tabular}{|c|c|c|c|c|c|c|}
\hline Breed & $\begin{array}{l}\text { No. of } \\
\text { sheep }\end{array}$ & Cold & $\begin{array}{l}\text { Cold plus } \\
\text { wind }\end{array}$ & $\begin{array}{l}\text { Cold plus } \\
\text { rain }\end{array}$ & $\begin{array}{l}\text { Cold plus } \\
\text { rain and } \\
\text { wind }\end{array}$ & $\begin{array}{l}\text { SE of } \\
\text { means }\end{array}$ \\
\hline Scottish Blackface & 3 & $29 \cdot 6$ & $37 \cdot 4$ & $35^{\cdot I}$ & $68 \cdot 0$ & \pm 3.8 \\
\hline Welsh Mountain & 2 & $29 \cdot 8$ & $4 I \cdot 6$ & $57 \cdot 7$ & $6 r \cdot 8$ & $\pm 8 \cdot 2$ \\
\hline Cheviot & 3 & $35 \cdot 3$ & $44 \cdot 8$ & $73 \cdot 3$ & $87 \cdot 7$ & $\pm 5^{\cdot 6}$ \\
\hline Suffolk Down & 4 & 34.0 & $37 \cdot 8$ & 53.7 & $69 \cdot 2$ & \pm 5.7 \\
\hline Kent & 4 & $30 \cdot 7$ & $38 \cdot 8$ & 53.5 & $63 \cdot I$ & $\pm 4 \cdot 5$ \\
\hline Hampshire Down & 4 & $3 I \cdot 4$ & $34 \cdot 2$ & 50.9 & $56 \cdot 4$ & $\pm 7 \cdot 5$ \\
\hline $\begin{array}{l}\text { Significance of } \\
\text { differences between } \\
\text { breeds }\end{array}$ & & NS & NS & $\begin{array}{l}0.05>P \\
>0.01\end{array}$ & $\begin{array}{l}0.05>P \\
>0.01\end{array}$ & \\
\hline
\end{tabular}

NS, not significant.

sheep with good fleeces can withstand. Comparison of the mean values for metabolism in periods of $24 \mathrm{~h}$ with those estimated from measurements made for $\mathrm{I} h$ by mask methods indicates that metabolism was apparently lower in the cold than in the warm environment of the respiration chamber. This was largely due to the fact that measure- 
ments by mask methods were made $4^{-8} \mathrm{~h}$ after the last meal and the marked elevation of heat production in the first $4 \mathrm{~h}$ after eating was ignored. Wind and rain both increased metabolism, and the combination of the two together was approximately additive and more than sufficient to double metabolism. The heat losses expressed per $\mathrm{m}^{2}$ surface per $24 \mathrm{~h}$ per ${ }^{\circ} \mathrm{C}$ gradient between rectal temperature and air temperature are given in Table 6 . The standard errors in the final column include variation between individual animals. Statistical tests of the significance of differences between breeds in the effects of wind and rain were made simply by analysis of the increments in conductance due to wind and to rain.

The response to wind varied from an increase in heat loss of $2 \cdot 8 \pm \mathrm{I} \cdot 9 \mathrm{kcal} / \mathrm{h} \mathrm{m}^{2}{ }^{\circ} \mathrm{C}$ gradient from the rectum to the air in the Hampshire sheep to $\mathrm{II} \cdot 8 \pm 2 \cdot 7 \mathrm{kcal} / \mathrm{h} \mathrm{m}^{2}{ }^{\circ} \mathrm{C}$ gradient in the Welsh Mountain sheep. The difference between these two observations was significant when $P=0.05$, and is understandable in view of the dense fleece of the Hampshire sheep which covers its head and legs and the open fleece and bare head and legs of the Welsh Mountain sheep. The increased heat loss due to wind for all the breeds did in fact appear to be inversely related to fleece density.

The response to artificial rain was least in the Scottish Blackface sheep $(5.5 \mathrm{kcal} /$ $\mathrm{h} \mathrm{m}^{2}{ }^{\circ} \mathrm{C}$ ), which has a fleece which sheds rain, and largest in the Cheviot sheep. The Cheviots showed considerable discomfort in the rain, and the very high response to artificial rain may be in part related to their attempts to avoid it. The response to joint effects of wind and rain were least in the Hampshire sheep and greatest in the Cheviots.

These results suggest that the differences in the fleece type and behaviour of the breeds under stress modify their reactions to cold stress.

\section{DISCUSSION}

We recognize that results obtained with such small groups of sheep of the same breed, mostly obtained from single flocks, do not allow estimates to be made of breed norms of metabolism. The obvious wide range of variation from breed to breed in their size, conformation, fleece type and behaviour, however, raised questions about whether equally large interbreed variations might occur in metabolism and food utilization. The experiment was not designed to estimate population means but to show whether variations from breed to breed in metabolism exceeded grossly the variations from sheep to sheep within a breed.

Generally it appears from this study that when metabolic measurements are expressed in such a way that they do not involve a measurement of body-weight no difference can be detected as between the breed groups. The losses of energy in faeces, in urine and as methane per unit of food ingested were the same for all the breeds, and so was the relative feeding level attained when feed was given ad lib., relative feeding level being defined as the ratio of measured intake of digested energy to maintenance requirement of energy. If, however, comparisons between the metabolic performances of the different groups entailed making some allowance for the size of the sheep, complications arose.

The fasting heat productions and maximal food intakes of small Welsh Mountain 
sheep are obviously smaller, in absolute terms, than those of large Cheviot sheep. To compare these two breeds with respect to their metabolism or appetite necessarily means taking into account the difference in their body size. Here difficulties abound for the weight of an individual sheep varies considerably with diet. One Welsh Mountain sheep, for example, during fasting weighed $32 \cdot 4 \mathrm{~kg}$ and when fed ad lib. $36.0 \mathrm{~kg}$. One Cheviot sheep weighed $53.9 \mathrm{~kg}$ when fasted and $69.7 \mathrm{~kg}$ when fed ad lib. The Cheviot weighed $66 \%$ more than the Welsh Mountain when they were fasted and $94 \%$ more when they were both fed.

The weight during fasting has been taken to be the more realistic measure of body size as far as measures of metabolism are concerned. When fasting metabolism is related to body-weight raised to the power 0.73 , which is the power function linking the metabolism of animals of different species to their fasted weight (Brody, 1945), then the group of Cheviot sheep had a high metabolism relative to that of other breeds. When, however, the evidence provided by the experiment itself was used, the power of weight was found to be 0.85 and breed differences disappeared. Again, when maximal intake of food was related to weight raised to the power 0.73 , the group of Cheviots ate significantly more than the other breeds. If the power 0.85 was used these differences disappeared. It seems on this basis that metabolic differences between breeds of sheep differing in body size are probably quite small, a conclusion in agreement with those comparisons not complicated by body size considerations. It is apparent, however, that breeds differ in their metabolic reaction to climatic stresses. These differences can be related to the very obvious differences in the fleeces of different breeds, but may well be related also to innate differences in behaviour of the breeds when subject to climatic stresses.

\section{REFERENCES}

Blaxter, K. L., Wainman, F. W. \& Davidson, J. (1966). F. Anim. Prod. 8. (In the Press.) Blaxter, K. L., Wainman, F. W. \& Wilson, R. S. (196I). Anim. Prod. 4, 35I.

Brody, S. (r945). Bioenergetics and Growth. New York: Reinhold Publishing Corp.

Joyce, J. P. (1964). The energy exchanges of ruminants. PhD Thesis, University of Glasgow.

Wainman, F. W. \& Blaxter, K. L. (1958). Publs Eur. Ass. Anim. Prod. no. 8, p.85. 